\title{
Pembaharuan Undang-Undang Perkawinan Perihal Poligami Berdasarkan Hukum Perkawinan
}

\author{
Yudi Prihartanto Soleh \\ Universitas Pasundan \\ Yudiprihartantos@gmail.com
}

\begin{abstract}
Polygamy is one of the problems in marriage that is most highlighted by the people of Indonesia as well as considered controversial. The issue of polygamy is one of the issues regulated in Indonesian marriage law. In principle, marriage is a mental bond between a man and a woman as a husband and wife with the aim of forming a family. The establishment of the Marriage Law in Article 3, on the one hand applying the principle of monogamy, but in the next verse opened the opportunity for husbands to propose polygamy. Renewal of the Marriage Law can be interpreted as an effort and deed through a certain process with full seriousness committed by the government who have competence and authority in the development of Marriage Law in ways that have been specified based on the rules of law.
\end{abstract}

Keywords: Polygamy, Marriage Law, Law Reform.

\begin{abstract}
Abstrak. Poligami merupakan salah satu persoalan dalam perkawinan yang paling banyak disoroti oleh kalangan masyarakat Indonesia sekaligus dianggap kontroversial. Masalah poligami merupakan salah satu isu yang diatur dalam hukum perkawinan Indonesia. Pada prinsipnya perkawinan adalah ikatan lahir bathin antara seorang pria dengan seorang wanita sebagai suami isteri dengan tujuan membentuk keluarga. Pembentukan UU Perkawinan pada Pasal 3, di satu sisi menerapkan azas monogami, tetapi di ayat berikutnya dibuka peluang bagi suami untuk mengajukan poligami. Pembaruan UU Perkawinan dapat diartikan sebagai upaya dan perbuatan melalui proses tertentu dengan penuh kesungguhan yang dilakukan oleh pemerintah yang mempunyai kompetensi dan otoritas dalam pengembangan UU Perkawinan dengan cara-cara yang telah di tentukan berdasarkan kaidah-kaidah hukum.
\end{abstract}

Kata Kunci: Poligami, UU Perkawinan, Pembaharuan Hukum.

\section{A. PENDAHULUAN}

\section{Latar Belakang}

Poligami adalah perkawinan seorang suami dengan lebih dari seorang isteri dalam waktu yang bersamaan. Lawan dari poligami adalah monogami. Dalam perspektif hukum Islam, poligami dibatasi sampai maksimal empat orang isteri. Salah satu ayat pokok yang dapat dijadikan acuan dilakukannya poligami, yakni QS. An-Nisa ayat (3). Poligami sudah berjalan seiring perjalanan sejarah umat manusia, sehingga poligami bukanlah suatu trend baru yang muncul tiba-tiba saja. Para ulama berbeda pendapat mengenai ketentuan dan hukum poligami. Di antara mereka ada yang menyetujui poligami dengan persyaratan yang agak longgar dan ada yang mempersyaratkannya dengan ketat. Di antara mereka juga ada yang melarang poligami, kecuali karena terpaksa (sebagai rukhshah) dalam kondisi-kondisi tertentu. 
Pelaksanaan poligami, menurut hukum Islam, harus didasari oleh terpenuhinya keadilan dan kemaslahatan di antara pihak-pihak yang terlibat di dalamnya. Namun, kenyataannya banyak praktik poligami yang tidak mengindahkan ketentuan hukum Islam tersebut, sehingga masih jauh dari yang diharapkan. Sebagian dari masyarakat kurang atau tidak setuju dengan poligami dan mereka menentang praktik poligami yang ada sekarang ini, karena efek negatifnya sangat besar bagi keluarga dan banyak menyakiti kaum perempuan. UU membolehkan atau memberi peluang untuk berpoligami bagi masyarakat yang telah memenuhi persyaratan. Hal ini mengindikasi bahwa keadilan yang dituntut oleh para pelaku poligami sudah diapresiasi.

Poligami merupakan salah satu persoalan dalam perkawinan yang sering dibicarakan dan menimbulkan kontroversi. Poligami memang dapat dilihat dengan beragam perspektif. Perspektif hukum merupakan pintu masuk (entry point) dalam memahami persoalan poligami. Masalah poligami merupakan salah satu isu yang diatur dalam hukum perkawinan Indonesia. (Soedharyo Soimin, 1992:4). Pada prinsipnya suatu perkawinan seorang pria hanya boleh mempunyai seorang isteri, maka poligami atau seorang suami beristeri dari dari seorang perempuan diperbolehakn apabil dikehendaki oleh pihak-pihak yang bersangkutan dan pengadilan telah memberi izin. Adapun alasan yang menjadi pedoman oleh pengadilan untuk dapat memberi izin poligami, ditegaskan dalam Pasal 4 ayat (2) UU
Perkawinan (Ahmad Rofiq, 1998:169172).

UU Perkawinan menganut asas monogami. Penegasan ini tertuang dalam Pasal 3 ayat (1). Dalam UU ini juga memperbolehkan seorang pria beristeri lebih dari satu. Dalam prakteknya, pengadilan tidak ketat menerapkan syarat-syarat yang sudah ditentukan. Acapkali suami melakukan tekanan lewat pengadilan agar isteri memperbolehkan suaminya poligami. Lebih lanjut di Pasal 3 ayat (2) UU Perkawinan diberikan ruang bagi seorang suami untuk berpoligami, dengan mengajukan "izin" kepada Pengadilan. Dalam hal ini, apabila diperhatikan secara seksama pada Pasal 3 ayat (1) dan ayat (2) UU Perkawinan terjadi pertentangan di mana pada ayat (1) dinyatakan pada azasnya UU Perkawinan mengandung prinsip monogami, akan tetapi di ayat (2) dibuka ruang poligami bagi seorang suami walaupun dalam Pasal berikutnya ditentukan syarat-syarat secara khusus. Poligami akan banyak menimbulkan konflik terutama prosedur administrasi, sehingga pernikahan poligami banyak dilakukan dengan cara nikah siri, dan banyaknya gugatan pembatalan perkawinan dengan alasan perkawinan poligami tanpa izin dari pengadilan pada umumnya dikabulkan dan perkawinannya dibatalkan. Permasalahan ini yang menjadi polemik dalam hukum perkawinan di Indonesia.

\section{B. PERUMUSAN MASALAH}

Berdasarkan uraian latar belakang perumusan masalahnya adalah bagaimana pembaharuan UU 
perkawinan perihal poligami berdasarkan hukum perkawinan agar dapat memberikan kepastian hukum dan keadilan.

\section{TUJUAN PENELITIAN}

Penelitian dilakukan dengan maksud untuk mencapai tujuan tertentu untuk mendapatkan gambaran mengenai konsep pembaharuan UU perkawinan perihal poligami berdasarkan hukum perkawinan agar dapat memberikan kepastian hukum dan keadilan.

\section{TINJAUAN TEORETIS PEMBAHARUAN UNDANG- UNDANG PERKAWINAN PERIHAL POLIGAMI BERDASARKAN HUKUM PERKAWINAN}

Perkawinan merupakan satusatunya cara untuk membentuk keluarga, karena perkawinan mutlak diperlukan sebagai syarat terbentuknya sebuah keluarga. Sebuah perkawinan dimulai dengan adanya rasa saling cinta dan kasih mengasihi antara kedua belah pihak suami dan istri yang senantiasa diharapkan berjalan dengan baik, kekal dan abadi yang didasarkan kepada Ketuhanan Yang Maha Esa. Perkawinan adalah sah apabila dilakukan menurut hukum masingmasing agamanya dan kepercayaannya itu. Sahnya suatu perkawinan selain harus menurut hukum agamanya, juga harus menurut kepercayaan dari agama yang dianut oleh calon mempelai bersangkutan. Negara berusaha untuk mengatur perkawinan dengan suatu UU nasional yang berlaku bagi seluruh warga Indonesia, yaitu dengan diundangkannya UU Perkawinan yang diharapkan dapat menciptakan unifikasi hukum di bidang hukum perkawinan (Wahyono dan Surini, 2004:1).

Perkawinan merupakan pertemuan yang teratur antar pria dan wanita dibawah satu atap untuk memenuhi kebutuhan-kebutuhan tertentu baik yang bersifat biologis, khusus, psikologis, sosial, ekonomi, maupun budaya bagi masing-masing, baik keduanya secara bersama-sama, dan bagi masyarakat di mana mereka hidup serta bagi kemanusiaan secara keseluruhan (Mantep Miharso, 2004:54). Allah tidak ingin menjadikan manusia itu seperti makhluk lainnya yang hidup bebas mengikuti nalurinya dan berhubungan antara jantan dan betinanya secara bebas dan tidak ada aturan yang mengaturnya. Demi menjaga martabat kemuliaan manusia, Allah menurunkan hukum sesuai dengan martabat manusia itu. Oleh karena itu, perkawinan di dalam Islam secara luas adalah:

1. Merupakan alat untuk memenuhi kebutuhan emosi dan seksual yang sah dan benar;

2. Suatu mekanisme untuk mengurangi ketegangan;

3. Cara untuk memperoleh keturunan yang sah;

4. Menduduki fungsi sosial;

5. Mendekatkan hubungan antar keluarga dan solidaritas kelompok;

6. Merupakan perbuatan menuju ketaqwaan; dan

7. Merupakan suatu bentuk ibadah yaitu pengabdian kepada Allah, mengikuti sunah Rasulullah SAW (Abdul Rahman I. Doi, 1996:7).

Poligami merupakan perkara yang telah lama sekali, namun tidak 
diketahui adanya aturan yang jelas, kecuali dalam syari'at Islam. Praktik poligami bukan hanya dilakukan oleh orang-orang yang beragama Islam saja, namun poligami merupakan sejarah seluruh ummat manusia. Pada asasnya dalam suatu perkawinan seorang pria hanya boleh mempunyai seorang istri, apabila seorang suami hendak beristri lebih dari satu orang maka harus mengajukan permohonan ke pengadilan dan adanya persetujuan dari istri yang sah, UU Perkawinan tidak melarang tetapi membatasi seorang suami untuk sulit beristri lebih satu, salah satu syaratnya adalah persetujuan dari istrinya, apabila perkawinan poligami tidak memenuhi syarat-syarat ketentuan yang diatur dalam UU Perkawinan. Pengaturan lebih lanjut mengenai poligami bagi pemeluk agama Islam terdapat juga dalam Inpres No. 1 Tahun 1991 tentang Kompilasi Hukum Islam, diatur Pasal 55 sampai dengan Pasal 59. Isi pasalpasal ini bersesuaian dengan ketentuan dalam hukum Islam, UU No. 1 Tahun 1974 tentang Perkawinan dan PP 9 Tahun 1975 tentang Pelaksanaan Undang-Undang Nomor 1 Tahun 1974. Ketentuan tersebut bertalian dengan persyaratan, pembatasan dan tatacara pengajuan permohonan izin poligami ke Pengadilan Agama.

Menurut Sudarsono, poligami adalah pernikahan antara seorang lakilaki dengan dua sampai empat perempuan. Sistem perkawinan seperti ini di dalam Islam memiliki ciri-ciri, sebagai berikut:

1. Yang dapat menikah lebih dari satu hanya pada pihak laki-laki. Oleh sebab itu perlakuan pernikahan yang menyimpang dari ciri ini dilarang dalam Islam;

2. Jumlahnya dibatasi, yaitu maksimal empat orang perempuan sesuai dengan surat An-Nisa' ayat 3;

3. Setiap poligami harus memenuhi syarat tertentu yaitu laki-laki dapat berbuat adil kepada isteri-isterinya, cinta, giliran menggauli dan nafkah (Sudarsono, 2005:60).

Dalam Islam poligami dikenal dengan istilah ta'adudu zaujah yang artinya adalah bertambahnya jumlah istri. Dengan demikian poligami dapat dikatakan perkawinan yang tidak terbatas. Term ini sebenarnya punya makna umum, yaitu memiliki dua orang atau lebih isteri dalam waktu yang bersamaan. Adapun kebalikan dari bentuk perkawinan seperti ini adalah monogami yaitu perkawinan di mana suami hanya memiliki satu orang isteri (Bibit Suprapto, 1999:71). Menurut Mahmud Syaltut, mantan rektor Universitas al-Azhar, Kairo, Mesir:

"Hukum poligami adalah mubah. Poligami dibolehkan selama tidak dikhawatirkan terjadinya penganiayaan terhadap para istri. Jika terdapat kekhawatiran terhadap kemungkinan terjadinya penganiayaan dan untuk melepaskan diri dari kemungkinan dosa yang dikhawatirkan itu, dianjurkan atau direkomendasikan agar mencukupkan beristri satu orang saja. Dengan demikian menjadi jelas, bahwa kebolehan berpoligami adalah terkait dengan terjaminnya keadilan dan ketiadaan kekhawatiran penganiayaan terhadap para istri" (Mahmud Syaltut, 1996:269). 
Poligami merupakan perkawinan di mana terdapat seorang suami yang menikahi beberapa orang wanita atau dapat dikatakan bahwa poligami adalah seorang suami yang mempunyai istri banyak. Di mana poligami tersebut berbeda regulasinya pada setiap negara. Poligami sebenarnya tidak diatur dalam UU perkawinan di Indonesia karena perkawinan di Indonesia menganut asas monogami yang terkandung dakam Undang-undang perkawinan dalam Pasal 3 ayat (2) UU Perkawinan, menyatakan asas monogami terbuka yang berarti bahwa seorang pria dapat mempunyai isteri lebih dari satu dengan persetujuan dari pihak-pihak yang bersangkutan dan izin dari pengadilan. Kompilasi Hukum Islam pun mengatur mengenai perkawinan poligami ini.

Pandangan hidup Pancasila dirumuskan dalam kesatuan lima sila yang masing-masing mengungkapkan nilai fundamental dan sekaligus menjadi lima sila operasional dalam menjalani kehidupan, termasuk dalam penyelenggaraan kegiatan menegara dan pengembanan hukum praktis. Kesatuan lima nilai fundamental itu bersama-sama dengan berbagai nilai yang dijabarkan atau diderivasi berdasarkannya, mewujudkan sebuah sistem nilai, dan dielaborasi (diejawantahkan) ke dalam berbagai asas hukum dan kaidah hukum yang keseluruhannya mewujudkan sebuah sistem hukum (tata hukum) (B. Arief Sidharta, 2013:98). Pokok pikiran yang mengatakan hukum sebagai sarana pembaharuan masyarakat, adalah:

"Sarana pembaharuan masyarakat didasarkan kepada anggapan bahwa adanya keteraturan atau ketertiban dalam usaha pembangunan dan pembaharuan itu merupakan suatu yang diinginkan atau dipandang (mutlak) perlu. Anggapan lain yang terkandung dalam konsepsi hukum sebagai sarana pembaharuan adalah bahwa hukum dalam arti kaidah atau peraturan hukum memang bisa berfungsi sebagai alat (pengatur) atau sarana pembangunan dalam arti penyalur arah kegiatan manusia ke arah yang dikehendaki oleh pembangunan dan pembaharuan" (Mochtar Kusumaatmadja, 1996: 13).

Dalam masyarakat yang sedang membangun (masyarakat yang sedang berubah), hukum tidak cukup memiliki fungsi sebagai alat untuk memelihara ketertiban dan kepastian saja, tetapi juga harus dapat membantu proses perubahan masyarakat yang sedang membangun, apabila perubahan hendak dilakukan dengan tertib dan teratur. Pengertian hukum di atas menunjukkan bahwa untuk memahami hukum secara holistik tidak hanya terdiri atas "asas" dan "kaidah", tetapi harus pula mencakup lembaga (institutions) yang diperlukan untuk "mewujudkan kaidah" itu dalam kenyataan. Keempat komponen hukum di atas, yaitu asas, kaidah, lembaga, dan proses bekerja sama secara integral untuk mewujudkan kaidah itu dalam kenyataan, dalam arti pembinaan hukum yang pertama dilakukan melalui hukum tertulis berupa peraturan perundang-undangan. Keempat komponen hukum yang diperlukan untuk "mewujudkan hukum" dalam kenyataan. Pembangunan membawa perubahanperubahan dalam kehidupan 
masyarakat. Perubahan yang dibawa pembangunan tentulah suatu perubahan yang diharapkan (positif), dan perubahan itu terjadi secara tertib dan teratur.

\section{E. METODE PENELITIAN}

Metode penelitian deskriptif analitis adalah metode yang mengkaji masalah-masalah dalam masyarakat dan tata cara yang berlaku dalam masyarakat serta situasi-situasi tertentu, termasuk tentang hubungan, kegiatan, sikap, pandangan, serta proses yang sedang berlangsung dan pengaruh-pengaruh dari suatu fenomena. (Moh. Nazir, 1999:63-64). Berkaitan dengan topik pembaharuan UU Perkawinan dalam perkawinan poligami berdasarkan hukum perkawinan di Indonesia, guna mendapatkan gambaran sebagaimana disebut di atas digunakan studi kepustakaan, yaitu menggunakan bahan hukum untuk menjawab masalah penelitian.

\section{F. PEMBAHASAN MENGENAI PENGATURAN POLIGAMI DAN PERANAN PEMERINTAH DALAM MEWUJUDKAN PEMBAHARUAN UU PERKAWINAN}

$$
\begin{aligned}
& \text { Perkawinan merupakan salah } \\
& \text { satu peristiwa penting dalam } \\
& \text { kehidupan manusia. Sudah menjadi } \\
& \text { kodrat alam bahwa setiap manusia } \\
& \text { memiliki naluri untuk saling tertarik } \\
& \text { baik bagi pria ataupun wanita terhadap } \\
& \text { lawan jenisnya. Dari perasaan tertarik } \\
& \text { ini kemudian timbul keinginan di } \\
& \text { antara dua manusia tersebut untuk } \\
& \text { membentuk sebuah kehidupan rumah } \\
& \text { tangga bersama. Dengan hidup } \\
& \text { bersama, kemudian melahirkan } \\
& \text { keturunan yang merupakan sendi }
\end{aligned}
$$

utama bagi pembentukan negara dan bangsa. Bentuk hidup bersama ini mempunyai akibat tertentu bagi masyarakat. Maka dari itu, dibutuhkan aturan dari hidup bersama mengenai syarat-syarat peresmian, pelaksanaan, kelanjutan, dan terhentinya kehidupan bersama tersebut. Aturan inilah yang disebut aturan perkawinan. Mengingat pentingnya lembaga perkawinan, negara berusaha untuk mengatur perkawinan dengan suatu undangundang nasional, yang dimaksudkan berlaku bagi seluruh warga Negara Indonesia (Wahyono dan Surini Ahlan, 2004:1).

Perkawinan poligami diberikan syarat adil yang tentu saja akan memberikan perlindungan hukum bagi pihak isteri yang dipoligami, sebagaimana firman Allah SWT dalam An-Nisa' ayat 129, menyatakan:

"Dan kamu tidak akan dapat berlaku adil di antara isteri-isteri (mu) walaupun kamu sangat ingin berbuat demikian, karena itu janganlah kamu terlalu cenderung (kepada yang kamu cinta) sehingga kamu biarkan yang lain terkatung-katung. Dan jika kamu mengadakan perbaikan dan memelihara diri (dari kecurangan), maka sungguh Allah Maha Pengampun, Maha Penyayang”.

Pedoman sebagai peraturan tentang poligami yaitu UU Perkawinan, PP Perkawinan, dan KHI. Berdasarkan UU Perkawinan, yang menyatakan bahwa: sistem kekeluargaan yang dianut oleh Negara Indonesia adalah pernikahan yang monogini/monogami (Pasal 3 ayat (1)). Dalam UU Perkawinan ini meskipun pada prinsipnya seseorang itu harus 
bermonogami/monogini akan tetapi pada penjelasan berikutnya memperbolehkan seseorang untuk berpoligami yaitu dengan ketentuan bahwa pengadilan dapat memberikan izin kepada suami untuk berpoligami dengan persetujuan pihak yang terkait (Pasal 3 ayat (2)). Kaitannya dengan hal ini, suami apabila menginginkan untuk berpoligami harus mengajukan permohonan kepada pengadilan setempat. Dalam hal ini, pengadilan terlebih dahulu mempertimbangkan kondisi isteri dalam hal moralitas dan kondisi kesehatan khususnya reproduksi. Setelah semua hal tersebut telah terpenuhi harus ada peresetujuan dari pihak-pihak yang bersangkutan bisa jadi persetujuan tersebut lisan atau tertulis yang penting disampaikan di muka pengadilan (Pasal 41 PP Perkawinan), dan jaminan kesejahteraan finansial yang dibuktikan dengan penghasilan, pajak penghasilan, dan keterangan lain yang dibutuhkan pengadilan dari suami (Pasal 4 dan Pasal 5 UU Perkawinan). Selain itu ada persyaratan yang pokok yang harus dipenuhi oleh seorang suami yaitu kebolehan poligami itu maksimal empat orang dan suami mampu untuk berlaku adil. Jika syarat tersebut tidak terpenuhi maka suami dilarang untuk melakukan poligami (Pasal 55 ayat (1), ayat (2), dan ayat (3) KHI).

Dengan adanya pasal-pasal
yang membolehkan poligami, walaupun dengan alasan dan syaratsyarat tertentu. Dengan demikian, dapat dikatakan bahwa negara Indonesia bukan negara yang menganut asas perkawinan monagami mutlak melainkan perkawinan monogami terbuka. Poligami juga tidak dapat dilakukan semena-mena oleh seorang suami melainkan, harus ada izin dari peradilan (hakim), sebagimana disebutkan dalam UU. Menurut Khoirudin Nasution, bahwa peraturan perundang-undangan perkawinan tentang poligami berusaha mengatur agar laki-laki yang melakukan poligami adalah laki-laki yang benar-benar, mampuh secara ekonomi menghidupi dan mencukupi seluruh kebutuhan (sandang, pangan, dan papan) keluarga (isteri-isteri dan anak-anak) dan mampuhh berlaku adil terhadap isteri-isterinya. Sehingga isteri-isteri dan anak-anak dari suami poligami tidak disia-siakan (Khoirudin Nasution, 2009:272).

Perkawinan berasal dari kata "kawin" yang menurut bahasa berati membentuk keluarga dengan lawan jenis, melakukan hubungan kelamin atau bersetubuh. Berasal dari kata annikah yang menurut bahasa berarti mengumpulkan, saling memasukan, dan wathi atau bersetubuh (Abdul Rahman Ghozali, 2003:8). Perkawinan bukan hanya ikatan lahir saja atau batin saja melainkan kedua unsur tersebut harus bersatu agar terjadi keseimbangan dalam hidup berkeluarga (rumah tangga). Sebagai ikatan lahir, perkawinan merupakan hubungan hukum antara seorang pria dan seorang wanita untuk hidup bersama sebagai suami istri. Bagi agama islah ikatan lahir ini terjadi dengan adanya upacara perkawinan yakni pengucapan akad nikah oleh calon mempelai pria kepada wali nikah mempelai wanita (ijab qobul), sedangkan bagi agama yang lain selain Islam yaitu pengucapan sesuai dengan 
ketentuan agama dan kepercayaan tersebut. Pengaturan poligami dalam peraturan perundang-undangan tentang perkawinan di Indonesia adalah dengan tujuan dibuat bukan untuk melarang poligami, melainkan untuk mengatur dan melindungi hak-hak wanita agar tidak terjadi tindakan sewenangwenang terhadap kaum wanita.

Kewajiban suami istri diatur dalam Pasal 30 sampai denganPasal 34 UU Perkawinan dan Pasal 80 sampai dengan 84 KHI. Di antara kewajiban tersebut ada kewajiban yang bersifat timbal balik antara suami istri dan ada kewajiban sepihak, yaitu kewajiban suami saja atau kewajiban istri saja. Kewajiban yang timbal balik antara suami istri adalah: wajib saling cinta mencintai, wajib saling hormat menghormati, setia, dan saling memberi bantuan lahir batin. Kewajiban sepihak dari suami: melindungi istri, menyediakan kebutuhan hidup rumah tangga sesuai dengan kemampuannya. Kewajiban sepihak dari istri: wajib mengatur urusan rumah tangga sebaik-baiknya. Dari sekian kewajiban yang diatur dalam UU Perkawinan dan KHI tersebut tidak ada aturan secara eksplisit mengenai kewajiban memenuhi kebutuhan seks. Memenuhi kebutuhan seks ini hanya mungkin dimasukkan dalam kewajiban timbal balik, yaitu saling memberi bantuan lahir dan bathin.

Tujuan perkawinan adalah membentuk keluarga yang bahagia dan kekal. Untuk itu suami isteri perlu saling membantu dan melengkapi, agar masing-masing dapat mengembangkan kepribadiannya membantu dan mencapai kesejahteraan spiritual dan materiel. UU Perkawinan menganut asas monogami. Hanya apabila dikehendaki oleh yang bersangkutan, karena hukum dan agama yang bersangkutan mengizinkannya, seorang suami daat beristeri dengan lebih dari seorang istri, meskipun hal itu dikehendaki oleh pihak-pihak yang bersangkutan, hanya dapat dilakukan apabila memenuhi berbagai persyaratan tertentu dan diputuskan oleh pengadilan. Karena tujuan perkawinan adalah untuk membentuk keluarga yang bahagia kekal dan sejahtera, maka UU Perkawinan menganut prinsip untuk mempersukar terjadinya perceraian. Hak dan kedudukan istri adalah seimbang dengan hak dan kedudukan suami baik dalam kehidupan rumah tangga maupun dalam pergaulan masyarakat, sehingga dengan demikian segala ssuatu dalam keluarga dapat dirundingkan dan diputuskan bersama oleh suami isteri.

UU Perkawinan, secara tertulis memberikan titik terang bagi pelaku poligami akan tetapi sebenarnya UU ini menekankan untuk lebih memilih untuk bermonogami. Hal ini terlihat jelas bagaimana syarat-syarat yang harus dipenuhi. Meskipun pertimbangan kondisi dari seorang isteri dinilai sangat rentan untuk tidak bahagia, lebih disebabkan karena ketidakberdayaan yang menjadi suratan takdir. Akan tetapi, UU lebih mendahulukan perasaan seorang isteri dari pada izin poligami. Seandainya ada izin dari isteri/isteri-isteri merupakan cerminan dari kewibawahan isteri/isteri-isteri. Betapa sangat lapang dada seorang isteri yang pada saat suaminya mengajukan izin 
kepadanya untuk berpoligami berada dalam suatu kondisi yang sangat membutuhkan perhatian dan dukungan. Suatu hal yang sebenarnya sulit diterima oleh naluri perasaan pada saat sang isteri didera beban yang sangat menghentakkan jiwa, suami menginginkan untuk membagi cintanya kepada yang lain. Dalam KHI menyantumkan bahwa pihak pengadilan memberikan ketentuan yang sangat ketat bagi suami yang menginginkan poligami. Pertimbangan pengadilan tidak hanya masalah materi yang dinilai cukup untuk beristeri lebih dari satu melainkan ada pertimbangan yang mendasar yaitu kemampuan suami untuk berlaku adil.

dalam $\begin{array}{r}\text { Perkembangan yang terjadi } \\ \text { masyarakat menimbulkan }\end{array}$ berbagai gejala-gejala sosial yang memicu suatu konflik. Konflik tersebut bukan hanya dalam lingkup masyarakat luas, tetapi juga merambah ke persoalan rumah tangga. Salah satu konflik yang sering terjadi dalam lingkungan rumah tangga terkait dengan perkawinan (pertalian). Perkawinan merupakan salah satu kebutuhan psikologis manusia. Melalui perkawinan, akan terbangun hubungan emosional antara dua orang yang disebut sebagai keluarga. Berdasarkan hukum positif yang berlaku, perkawinan pada dasarnya menganut asas monogami. Asas ini hanya memberikan peluang seorang pria mempunyai seorang istri, dan begitu juga sebaliknya. Hal itu telah diatur secara limitatif dalam Pasal 3 ayat (1) UU Perkawinan. Pernikahan monogami sebagaimana ketentuan di atas dapat dikesampingkan sebagaimana syarat yang ditentukan dalam Pasal 3 ayat (2) UU Perkawinan. Pasal tersebut menyatakan pengadilan berwenang memberi izin kepada seorang suami untuk beristri lebih dari seorang apabila dikehendaki oleh para pihak, atau disebut poligami (Rochxy dan Bayu Lesmana, 2016:251).

Perkawinan merupakan hal yang sangat penting dalam suatu masyarakat karena dengan adanya suatu perkawinan maka akan menimbulkan ikatan antara seorang laki-laki dengan seorang wanita. Ikatan tersebut dimaksudkan untuk membentuk sebuah keluarga bahagia dengan tujuan untuk mendapatkan keturunan. Sistem hukum yang dimiliki oleh berbagai bangsa dan negara tidak sama. Dengan sendirinya konsep atau pengertian perkawinan yang dianut oleh berbagai sistem hukum itu pun tidak sama (Nita Ariyulinda, 2014:1). Bagi masyarakat Indonesia sudah menjadi pegangan hidup bahwa mengenai perkawinan, kelahiran, dan kematian sangat dipengaruhi oleh ketentuan-ketentuan agama. Terutama lagi setelah kedatangan agama-agama besar di Indonesia maka masalah perkawinan sangat dipengaruhi oleh ajaran-ajaran dan ketentuan agama yang bersangkutan. Sebagaimana diketahui masalah perkawinan yang diatur dalam Pasal 2 UU Perkawinan.

Menurut UU Perkawinan, sahnya suatu perkawinan adalah merujuk pada dasar hukum Pasal 1 yang menyatakan: "Perkawinan adalah ikatan lahir batin antara seorang pria dan seorang wanita sebagai suami istri dengan tujuan membentuk keluarga (rumah tangga) yang bahagia dan kekal berdasarkan Ketuhanan Yang Maha 
Esa". Menurut Pasal 3, Pasal 4, dan Pasal 5 UU Perkawinan, persetujuan istri seringkali menjadi persoalan inti dalam poligami, di mana seorang suami melakukan perkawinan untuk kedua kalinya atau lebih tanpa izin dari istri yang pertama (terdahulu). Pada dasarnya, perkawinan yang dikehendaki yaitu perkawinan yang dilakukan untuk waktu selamalamanya sampai meninggalnya salah seorang suami atau istri. Perkawinan bertujuan membentuk keluarga (rumah tangga) yang bahagia, berarti dalam rumah tangga itu seharusnya tercipta adanya hubungan yang harmonis antara suami istri dan anggota keluarganya berdasarkan adanya prinsip saling menghormati (menghargai) dengan baik, tenang, tenteram dan saling mencintai dengan tumbuhnya rasa kasih sayang.

\section{KHI merupakan hasil} konsensus (ijma') ulama dari berbagai "golongan"melalui media lokakarya yang dilaksanakan secara nasional yang kemudian mendapat legalisasi dari kekuasaan Negara. Yang mana kompilasi hukum Islam ini bertujuan untuk memositifkan hukum islam di Indonesia. Dalam kaitan ini kata hukum islam harus diartikan sebagai Hukum Perdata Islam (Abdul Rahmat Budiono, 2003:32). Walaupun pada dasarnya asas yang melekat dalam UU Perkawinan tersebut merupakan asas monogami (Moh. Idris Ramulyo, 1996:184). Namun menurut Yahya Harahap, asas hukum dalam UU tersebut tidaklah berimplikasi pada asas monogami mutlak akan tetapi asas monogami terbuka (M. Yahya Harahap, 1975:25-26). Sementara asas yang melekat pada KHI adalah asas poligami tertutup. Sebab secara tersurat dalam Pasal 55 ayat (1) KHI, dijelaskan bahwa asas perkawinanya adalah poligami. Namun pasal-pasal setelahnya mengindikasikan untuk menutup asas poligami tersebut dengan berbagai persyaratan yang begitu ketat, sehingga tidak memungkinkan bagi para pelaku poligami untuk menerapkannya dengan sewenangwenang. Kedua asas tersebut tentunya terdapat konsekuensi hukum yang sama, yaitu poligami diperbolehkan di negara Indonesia.

Dalam pembentukan UU Perkawinan pada Pasal 3, apabila diperhatikan struktur norma, di satu sisi menerapkan azas monogami, tetapi di ayat berikutnya dibuka peluang bagi suami untuk mengajukan poligami. Dalam hal Pasal 3 ayat (1) dan ayat (2) melihat azas monogomi dan dibuka peluang untuk poligami berdasarkan izin, dirasakan tidak memberikan kepastian hukum dan keadilan bagi pelaku poligami. Masalah pengaturan poligami seharusnya menjadi azas dalam pembentukan UU Perkawinan karena dalam QS An-Nisa' ayat (3) bahwa suami berhak untuk berpoligami. Dalam KHI secara tegas bahwa perkawinan menurut Hukum Islam adalah pernikahan, yaitu akad yang sangat kuat untuk menaati perintah Allah dan melaksanakannya merupakan ibadah. Poligami merupakan syari'at Islam yang tidak dilarang dengan sarang dapat berlaku "adil". Banyaknya permasalahan dalam poligami di Indonesia, sudah saatnya pemerintah Indonesia untuk melakukan pembaharuan terhadap UU Perkawinan agar memberikan kepastian hukum dan perlindungan. 
Hukum mempunyai fungsi untuk memberikan perlindungan terhadap kepentingan manusia (seluruh manusia tanpa terkecuali). Oleh karena itu, maka hukum harus dilaksanakan agar kepentingan manusia tersebut dapat terlindungi. Dalam pelaksanaannya, hukum dapat berlangsung secara normal dan damai, akan tetapi dapat juga terjadi pelanggaran-pelanggaran hukum dalam prakteknya. Dalam hal ini hukum yang telah dilanggar itu harus ditegakkan. Melalui penegakan hukum inilah hukum ini menjadi kenyataan. Dalam menegakan hukum ada tiga unsur yang selalu harus diperhatikan, yaitu kepastian hukum, kemanfaatan dan keadilan. Dalam pembaharuan UU Perkawinan sudah seharusnya memperhatikan asas-asas dalam pembentukan peraturan perundangundangan sehingga dalam pemberlakuannya dapat memberikan kepastian hukum apabila terjadi sengketa atau konflik sehingga rasa keadilan masyarakat dapat terwujud.

Problem hukum pertama jika diukur dengan asas hukum perkawinan yang dianut oleh UU Perkawinan, yaitu perkawinan monogami dalam rangka melindungi hak-hak istri, maka persetujuan istri tersebut merupakan hak prerogatif istri sehingga siapapun atau lembaga apapun tidak boleh ikut campur mempengaruhi kehendak istri. Dalam rangka mewujudkan pembaharuan hukum perkawinan, perlu ditentukan arah dan strategi untuk memperoleh cara mencapai politik hukum yang telah dicanangkan. Sektor hukum perkawinan perlu memperoleh arah pembaharuan materi hukumnya. Pilihan sektor hukum perkawinan ini didasarkan pada urgensi dan besar pengaruhnya (impact) bagi kelangsungan tujuan bernegara sebagaimana disebutkan dalam Pembukaan UUD 1945, yaitu: "untuk membentuk suatu Pemerintahan Negara Indonesia yang melindungi segenap bangsa Indonesia dan seluruh tumpah darah Indonesia dan untuk memajukan kesejahteraan umum, mencerdaskan kehidupan bangsa dan ikut melaksanakan ketertiban dunia yang berdasarkan kemerdekaan, perdamaian abadi dan keadilan sosial".

Pada azasnya, perkawinan seperti ini dibolehkan bagi seorang muslim dalam arti yang sebenarnya dan sanggup berlaku adil terhadap istri-istrinya. Pembaharuan UU Perkawinan dirasakan sangat mendesak apabila melihat lahirnya pada tahun 1974, terutama terhadap rumusan Pasal 3 UU Perkawinan yang seharusnya menerapkan azas poligami dengan syarat-syarat yang sekarang sudah ada, sehingga tidak terjadi perdebatan di masyarakat. Pembaruan UU Perkawinan dapat diartikan sebagai upaya dan perbuatan melalui proses tertentu dengan penuh kesungguhan yang dilakukan oleh pemerintah yang mempunyai kompetensi dan otoritas dalam pengembangan UU Perkawinan dengan cara-cara yang telah di tentukan berdasarkan kaidah-kaidah hukum yang dibenarkan sehingga menjadikan UU Perkawinan dapat tampil lebih segar dan modern, tidak ketinggalan zaman.

\section{G. PENUTUP}

\section{Kesimpulan}

UU Perkawinan menganut asas 
monogami, hanya apabila dikehendaki oleh yang bersangkutan, karena hukum dan agama yang bersangkutan mengizinkannya, seorang suami dapat beristeri dengan lebih dari seorang istri, meskipun hal itu dikehendaki oleh pihak-pihak yang bersangkutan, hanya dapat dilakukan apabila memenuhi berbagai persyaratan tertentu dan diputuskan oleh pengadilan. Dalam pembentukan UU Perkawinan, di satu sisi menerapkan azas monogami, tetapi di ayat berikutnya dibuka peluang bagi suami untuk mengajukan poligami. Pembaruan UU Perkawinan dapat diartikan sebagai upaya dan perbuatan melalui proses tertentu dengan penuh kesungguhan yang dilakukan oleh pemerintah yang mempunyai kompetensi dan otoritas dalam pengembangan UU Perkawinan dengan cara-cara yang telah di tentukan berdasarkan kaidah-kaidah hukum.

\section{Saran}

Problem hukum pada asas hukum perkawinan yang dianut oleh UU Perkawinan, yaitu perkawinan monogami dalam rangka melindungi hak-hak istri, tetapi dibuka ruang bagi suami untuk berpoligami, diharapkan pemerintah dapat melaksanakan pembaharuan UU Perkawinan sehingga memberikan kejelasan azas dalam UU Perkawinan sehingga tidak menimbulkan multi tafsir terhadap norma dalam UU Perkawinan tersebut.

\section{DAFTAR PUSTAKA}

\section{Buku}

Abdul Rahman I. Doi. 1996. Perkawinan dalam syariat Islam. Jakarta: Rineka Cipta.
Abdul Rahmat Budiono. 2003. Peradilan Agama dan Hukum Islam Di Indonesia. Malang: Bayumedia. Ahmad Rofiq. 1998. Hukum Islam di Indonesia. Jakarta: Grmaedia Pustaka Utama.

Bernard Arief Sidharta. 2013. Ilmu Hukum, Upaya Pengembangan Ilmu Hukum Sistematik Yang Responsif Terhadap Perubahan Masyarakat. Yogyakarta: Genta Publishing.

Bibit Suprapto. 1999. Liku-liku Poligami. Yogyakarta: Al Kautsar.

Khoirudin Nasution. 1996. Riba dan Poligami: Sebuah Studi Atas Pemikiran Muhammad 'Abduh. Yogyakarta: Pustaka Pelajar.

Mahmud Syaltut. 1996. Islam 'Aqidah Wa Syari'ah. Mesir: Dar al-Qalam.

Mantep Miharso. 2014. Pendidikan Keluarga Qur'ani. Yogyakarta: Safria Insani Press.

Mochtar Kusumaatmadja. 1996. Hukum, Masyarakat dan Pembinaan Hukum Nasional, Suatu Uraian tentang Landasan Pikiran, Pola dan Mekanisme Pembaharuan Hukum di Indonesia, Bandung: Binacipta.

Moh. Idris Ramulyo. 1996. Hukum Perkawinan Islam: Suatu Analisa Dari UU No 1 Tahun 1974 dan Kompilasi Hukum Islam. Jakarta: Bumi Aksara.

Moh. Nazir. 1999. Metode Penelitian. Jakarta: Ghalia Indonesia.

Soedharyo Soimin. 1992. Hukum Orang dan Keluarga. Jakarta: Hadi Karya Agung.

Wahyono dan Surini Ahlan. 2004. Hukum Perkawinan dan Keluarga. Jakarta: Badan Penerbit Universitas Indonesia.

Yahya Harahap., M. 1975. Hukum Perkawinan Nasional. Medan: Zahir Trading.

\section{Peraturan Perundang-undangan}

Undang-Undang Dasar Negara
Republik Indonesia Tahun 1945 
Amandemen Keempat.

Undang-Undang Nomor 1 Tahun 1974 tentang Perkawinan (Lembaran Negara Tahun 1974 Nomor 1, Tambahan Lembaran Negara Nomor 3019).

Peraturan Pemerintah Republik Indonesia Nomor 9 Tahun 1975 tentang Pelaksanaan UndangUndang Nomor 1 Tahun 1974 tentang Perkawinan (Lembaran Negara Tahun 1975 Nomor 12, Tambahan Lembaran Negara Nomor 3050).

Instruksi Presiden Republik Indonesia Nomor 1 Tahun 1991 tentang Penyebarluasan Kompilasi Hukum Islam.

\section{Sumber Lain}

Khoirudin Nasution. 2009. Hukum Perdata (Keluarga) Islam Indonesia dan Perbandingan Hukum Perkawinan di Dunia Muslim Studi Sejarah, Metode Pembaruan, dan Materi dan Status Perempuan Dalam Perundang-undangan.

Yogyakarta: ACAdeMIA dan TAZZAFA.

Rochxy dan Bayu Lesmana. 2016. Pemidaan Terhadap Pelaku Perkawinan di Bawah Tangan Tanpa Izin Isteri Pertama. Jurnal Yudisial Vol. 6 No. 3 Desember. 